medRxiv preprint doi: https://doi.org/10.1101/2021.04.12.21255304; this version posted April 13, 2021. The copyright holder for this preprint (which was not certified by peer review) is the author/funder, who has granted medRxiv a license to display the preprint in perpetuity.

All rights reserved. No reuse allowed without permission.

\title{
Survey of Behaviour Attitudes Towards Preventive Measures Following COVID-19
}

\section{$\underline{\text { Vaccination }}$}

\section{Authors:}

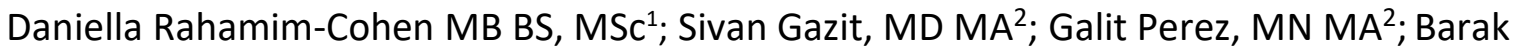
Nada, Bsc ${ }^{2}$; Shay Ben Moshe, MSc ${ }^{3,2}$; Miri Mizrahi-Reuveni MD MHA ${ }^{1}$; Joseph Azuri MD $\mathrm{MHA}^{1,4} ;$ Tal Patalon, $\mathrm{MD}^{2}$

\footnotetext{
${ }^{1}$ Health Division, Maccabi Healthcare Services, Tel Aviv, Israel.

${ }^{2}$ Kahn Sagol Maccabi (KSM) Research \& Innovation Center, Maccabi Healthcare Services, Israel.

${ }^{3}$ Ben-Gurion University, Beer Sheva, Israel.

${ }^{4}$ Sackler Faculty of Medicine, Tel Aviv University, Tel Aviv, Israel.

The authors declare they have no conflict of interest.
}

Corresponding author: Daniella Rahamim-Cohen

cohen dani@mac.org.il, HaMared 27, Tel Aviv, 68125, Israel

\section{Abstract:}

Following the widespread vaccination program for COVID-19 carried out in Israel, a survey was conducted to preliminarily assess behavior changes in the vaccinated population, prior to the expected upcoming policy change as to mask wearing and social distancing regulation in Israel. 200 people answered at least one question pertaining to preventive behaviour. Among the respondents, $21.1 \%$ reported a decrease in mask wearing compared to $47.3 \%$ who reported a decrease in social distancing. There was no difference in these measures between the sexes. However, people under the age of 50 were more likely to decrease mask wearing (28.1\%) and decrease social distancing (56.1\%), as compared with people over the age of 50 (17.2\% and $41.8 \%$, respectively). Among health care workers, there was a minimal decrease in mask wearing (1/23 people) compared to a more widespread decrease in social distancing (10/23). These data suggest that preventive attitudes change following COVID-19 vaccination, with less adherence to social distancing as compared to mask wearing, and should be taken

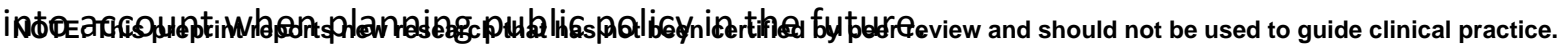


medRxiv preprint doi: https://doi.org/10.1101/2021.04.12.21255304; this version posted April 13, 2021. The copyright holder for this preprint (which was not certified by peer review) is the author/funder, who has granted medRxiv a license to display the preprint in perpetuity.

All rights reserved. No reuse allowed without permission.

\section{Introduction:}

Since the onset of the COVID-19 global pandemic in late 2019, there have been over 130,000 million reported cases with over 3 million deaths worldwide. Most countries set various guidelines and procedures in an attempt to curb the spread of the virus, including the use of personal protective equipment (PPE) and maintaining social distancing. These measures were found to be very effective in reducing viral transmission rate ${ }^{1}$ and were the cornerstones for health policy in tackling virus spread in most countries around the world, manifesting in lockdowns and various enforcement measures to ensure compliance.

With the introduction of vaccines against the virus, the question arises about a possible change in personal attitudes and behaviours to the recommendations for mask wearing and keeping social distancing.

Evidence from previous vaccine rollouts suggests that there may be a decrease in adherence to preventive behaviours. Following the Lyme disease vaccine rollout, there was a decrease in the use of light color clothing and tick repellent ${ }^{2}$. An evaluation of behvaiour following the influenza vaccine's rollout showed that people interacted with more people and in larger groups $^{3}$.

Israel began vaccinating its population at the end of December 2020, using the Pfizer/BioNtech BNT162b2 COVID-19 vaccine. The vaccination program was implemented through HMO's and hospitals, with clear prioritization - beginning with the elderly and 
medRxiv preprint doi: https://doi.org/10.1101/2021.04.12.21255304; this version posted April 13, 2021. The copyright holder for this preprint (which was not certified by peer review) is the author/funder, who has granted medRxiv a license to display the preprint in perpetuity.

All rights reserved. No reuse allowed without permission.

medical staff, until the current situation where any citizen over the age of 16 is eligible to receive a vaccine.

As of April $8^{\text {th }}, 52.8 \%$ of the Israeli population has completed the course of two vaccinations ${ }^{4}$ with over 5 million people vaccinated. Since the beginning of the program, Israel has seen a steady decrease in confirmed COVID-19 cases and mortality. As a result of the improvement in morbidity and mortality and the high vaccination uptake, the government has lifted many of the restrictions imposed on the population over the past year, opening shops, restaurants, and schools. Some are accessible only to fully vaccinated individuals. However, the policy to wear masks indoors and outdoors and maintain social distancing is still in effect and has not officially changed.

The possible effect of the COVID-19 vaccination program on adherence to the rules and regulations surrounding personal protective behaviour is central to formulating health policy regarding the virus in the vaccination and post-vaccination era. The UK has prepared an executive summary regarding the possible impact of widespread vaccination on adherence outcomes and how they can be mitigated ${ }^{5}$. To assess Israel's situation and explore if there are behavioural changes in the population following vaccination, we conducted a survey to identify behaviour attitudes in the general vaccinated population within Maccabi Healthcare Services (MHS).

\section{Method:}

A survey was sent by a text message to 2500 subjects, randomly seleted, above the age of 18 , vaccinated or not vaccinated, from MHS, the second largest HMO in Israel, serving 
medRxiv preprint doi: https://doi.org/10.1101/2021.04.12.21255304; this version posted April 13, 2021. The copyright holder for this preprint (which was not certified by peer review) is the author/funder, who has granted medRxiv a license to display the preprint in perpetuity.

All rights reserved. No reuse allowed without permission.

approximately 2.5 million people (about a quarter of the Israeli population) with nationwide distribution. The survey was conducted between $25 / 3 / 21-7 / 4 / 21$. Participants were asked to compare mask-wearing and social distancing before and after the vaccination. Demographics included age, sex, and being a healthcare professional.

The following analysis is preliminary, as we are currently conducting further research exploring the influence of the upcoming healthcare policy changes.

The study was approved by the MHS institutional review board.

\section{$\underline{\text { Results: }}$}

Of 2500 surveys sent, 200 people aged $18-80$ years responded to at least one question. The average time for answering was 3:39 minutes. Thirteen respondents were not vaccinated with even one vaccination. The main results are described in Table 1.

Following the second vaccination, 39 respondents reported "lower mask wearing" than before receiving the vaccination (21.1\%) compared to 140 who did not change their mask wearing behaviour (75.7\%) [Figure 1]. There was no substantial difference in terms of sex or being a healthcare professional in terms of decreased mask wearing; however, more people aged less than 50 decreased their mask wearing, 28.1\% (16/57) compared to the group aged 50 and above, $17.2 \%(21 / 122)$.

When comparing social distancing behavior before and after vaccination, 89 (48.4\%) reported no change, whereas $87(47.3 \%)$ respondents reported a decrease in social distancing [Figure 
medRxiv preprint doi: https://doi.org/10.1101/2021.04.12.21255304; this version posted April 13, 2021. The copyright holder for this preprint (which was not certified by peer review) is the author/funder, who has granted medRxiv a license to display the preprint in perpetuity.

All rights reserved. No reuse allowed without permission.

2]. There was only a slight difference between males and females (38/80, 47.5\%; 49/104, $47.1 \%$, respectively).

Of the respondents aged 50 and above, $41.8 \%$ (51/122) reported keeping "less social distancing", while 53.3\% (65/122) reported no change, whereas respondents below the age of 50 reported $56.1 \%(32 / 57)$ and $40.4 \%(23 / 57)$ respectively.

Only one healthcare professional reported decreased "mask wearing" following the vaccine $(1 / 23)$, in comparison to almost half $(10 / 23)$ of the healthcare professionals who reported a decrease in "social distancing" following the vaccine.

\section{Discussion}

Consistent with previous findings ${ }^{2,3}$, the survey showed decreased social distancing and mask wearing in specific population groups following COVID-19 vaccination. The reported decrease in mask wearing was less prevalent than the reported decrease in social distancing, which occurred in approximately half the surveyed population. In the subgroup of health professionals, it is clear that maintaining mask-wearing is still the prevailing practice, as opposed to maintaining social distancing.

Moreover, the survey suggests that people under the age of 50 are less likely to maintain the preventive behaviours of mask wearing and social distancing when compared to the older population. 
medRxiv preprint doi: https://doi.org/10.1101/2021.04.12.21255304; this version posted April 13, 2021. The copyright holder for this preprint (which was not certified by peer review) is the author/funder, who has granted medRxiv a license to display the preprint in perpetuity.

All rights reserved. No reuse allowed without permission.

Although the data above is not surprising, it should be taken into account when devising health policy regarding COVID-19 preventive behaviour in populations that have been widely vaccinated.

\section{Limitations}

The current survey is a preliminary effort to assess health behaviour in vaccinated population, prior to the upcoming policy change as to mask wearing and social distancing regulation in Israel. The cohort is relatively small, without statistical analysis. Availability of cell phone use among different populations (e.g. ultraorthodox, elderly) is of consideration, as further studies will address these issues.

\section{References:}

1. Chu, D. K. et al. Physical distancing, face masks, and eye protection to prevent person-to-person transmission of SARS-CoV-2 and COVID-19: a systematic review and meta-analysis. Lancet 395, 1973-1987 (2020).

2. Brewer, N. T., Cuite, C. L., Herrington, J. E. \& Weinstein, N. D. Risk compensation and vaccination: Can getting vaccinated cause people to engage in risky behaviors? Ann. Behav. Med. 34, 95-99 (2007).

3. Reiber, C. et al. Change in human social behavior in response to a common vaccine. Ann. Epidemiol. 20, 729-733 (2010).

4. COVID-19 in Israel dashboard. (2021).

5. SPI-B: Possible impact of the COVID-19 vaccination programme on adherence to rules and guidance about personal protective behaviours aimed at preventing spread of the virus. 


\section{Figures and Tables}

Table 1. Main results.

\begin{tabular}{|l|l|l|l|l|l|l|l|}
\hline \multicolumn{2}{|c|}{} & All & Male & Female & Age $<\mathbf{5 0}$ & Age $\mathbf{2 5 0}$ & $\begin{array}{l}\text { Health } \\
\text { workers }\end{array}$ \\
\hline \multirow{4}{*}{$\begin{array}{l}\text { Mask usage } \\
\text { post } \\
\text { vaccination }\end{array}$} & Responded & 185 & 80 & 105 & 57 & 122 & 23 \\
\cline { 2 - 7 } & Lower & 39 & 16 & 23 & 16 & 21 \\
$(21.1 \%)$ & $(20.5 \%)$ & $(21.9 \%)$ & $(28.1 \%)$ & $(17.2 \%)$ & $1(4.3 \%)$ \\
\cline { 2 - 8 } & No change & $\begin{array}{l}140 \\
(75.7 \%)\end{array}$ & $\begin{array}{l}62 \\
(77.5 \%)\end{array}$ & $\begin{array}{l}78 \\
(74.3 \%)\end{array}$ & $\begin{array}{l}40 \\
(70.2 \%)\end{array}$ & $\begin{array}{l}97 \\
(79.5 \%)\end{array}$ & $\begin{array}{l}22 \\
(95.7 \%)\end{array}$ \\
\cline { 2 - 8 } & Higher & $6(3.2 \%)$ & $2(2.5 \%)$ & $4(3.8 \%)$ & $1(1.8 \%)$ & $4(3.3 \%)$ & $0(0 \%)$ \\
\hline \multirow{4}{*}{$\begin{array}{l}\text { Social } \\
\text { distancing } \\
\text { post } \\
\text { vaccination }\end{array}$} & Responded & 184 & 80 & 104 & 57 & 122 & 23 \\
\cline { 2 - 8 } & Lower & $\begin{array}{l}87 \\
(47.3 \%)\end{array}$ & $\begin{array}{l}38 \\
(47.5 \%)\end{array}$ & $\begin{array}{l}49 \\
(47.1 \%)\end{array}$ & $\begin{array}{l}32 \\
(56.1 \%)\end{array}$ & $\begin{array}{l}51 \\
(41.8 \%)\end{array}$ & $\begin{array}{l}10 \\
(43.5 \%)\end{array}$ \\
\cline { 2 - 8 } & No change & $\begin{array}{l}89 \\
(48.4 \%)\end{array}$ & $\begin{array}{l}39 \\
(48.8 \%)\end{array}$ & $\begin{array}{l}50 \\
(48.1 \%)\end{array}$ & $\begin{array}{l}23 \\
(40.4 \%)\end{array}$ & $\begin{array}{l}65 \\
(53.3 \%)\end{array}$ & $\begin{array}{l}12 \\
(52.2 \%)\end{array}$ \\
\cline { 2 - 8 } & Higher & $8(4.3 \%)$ & $3(3.8 \%)$ & $5(4.8 \%)$ & $2(3.5 \%)$ & $6(4.9 \%)$ & $1(4.3 \%)$ \\
\hline
\end{tabular}

Figure 1. Mask wearing behaviour post vaccination

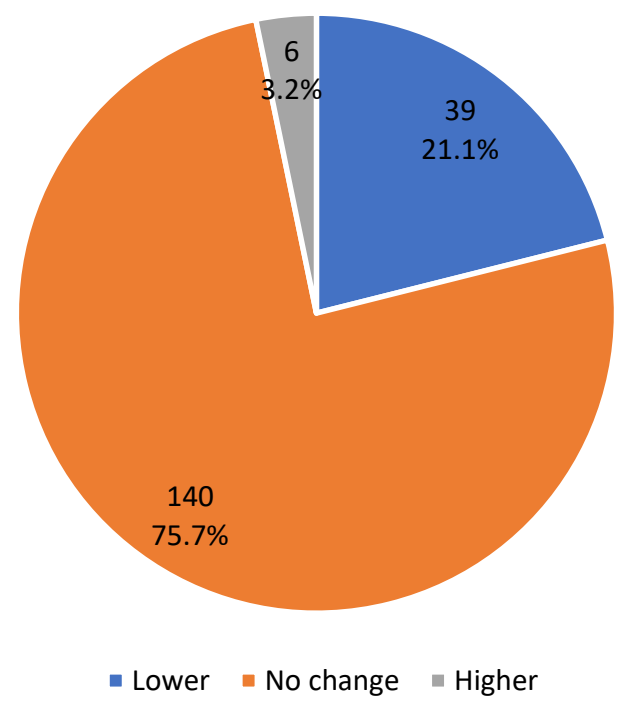


medRxiv preprint doi: https://doi.org/10.1101/2021.04.12.21255304; this version posted April 13, 2021. The copyright holder for this preprint (which was not certified by peer review) is the author/funder, who has granted medRxiv a license to display the preprint in perpetuity.

All rights reserved. No reuse allowed without permission.

Figure 2. Social distancing practices post vaccination

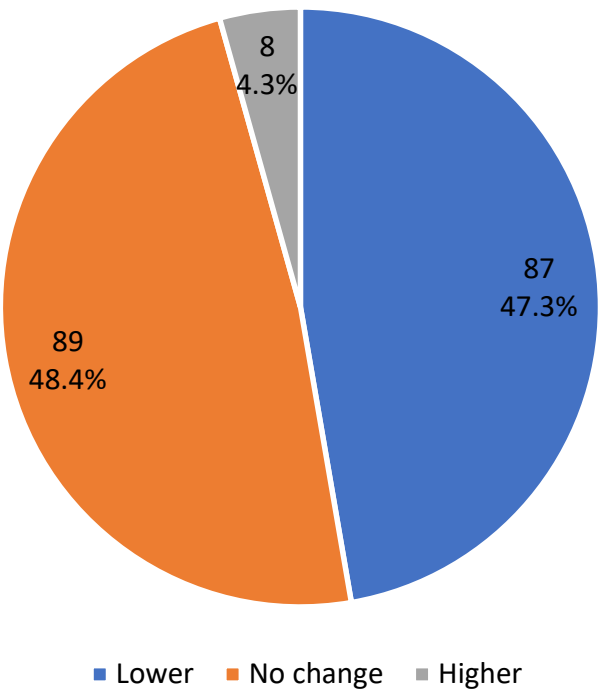

